\title{
KUALITAS PELAYANAN PEMBUATAN PASPOR DI KANTOR IMIGRASI KELAS I KOTA BOGOR
}

\section{QUALITY OF SERVICE IN THE OFFICE OF IMMIGRATION PASSPORT MAKING CLASS I KOTA BOGOR}

\author{
Suciani Cahya Bintari1a, H. Nandang Saefudin Zenju ${ }^{2}$, Irma Purnamasari ${ }^{3}$ \\ ${ }^{1}$ Jurusan Ilmu Administrasi Negara Fakultas Imu Sosial dan Ilmu Politik Universitas Djuanda, Jl.Tol \\ Ciawi No 1, Kotak Pos 35 Bogor 16770 \\ 2 Jurusan Ilmu Administrasi Negara Fakultas Imu Sosial dan Ilmu Politik Universitas Djuanda, Jl.Tol \\ Ciawi No 1, Kotak Pos 35 Bogor 16770 \\ 3 Jurusan Ilmu Administrasi Negara Fakultas Imu Sosial dan Ilmu Politik Universitas Djuanda, Jl.Tol \\ Ciawi No 1, Kotak Pos 35 Bogor 16770
}

(Diterima oleh Dewan Redaksi: 01-02-2017)

(Dipublikasikan oleh Dewan Redaksi: 01-04-2017)

\begin{abstract}
The purpose of this study is to determine the passport service quality at Class I Immigration Office of Bogor.

The theory used in this research is put forward by Parasuraman, Berry and Zeithaml (Ratminto \& Septi Winarsih, 2005: 175), which consists of five dimensions of service quality : Tangible, Reliability, Responsiveness, Assurance and Empathy. The method used is descriptive analysis using quantitative approach. Data analysis technique used is the calculation of Weight Mean Score (WMS). Data collection techniques used are literature studies and field studies. The study population consists of 220 respondents consisting of Applicants and Passport Officers. While the sampling technique used is the saturated technique sampling to officers and incidental sampling to the applicants. The samples using Yamane formula so that the samples obtained are 87 respondents.

Research result of service quality in making passport at Bogor immigration office is considered to be good, because of the processing of a questionnaire made to the applicant's passport 67 samples obtained is score of 3.67 (in scale of 5), which is included in the "good" category. Nevertheless there are many grievances felt by the applicant. This occurs due to less extent of the lounge to the applicant, the speed of completing the passport, guarantee timely completion of the passport, and the discriminatory treatment which actually is for the elderly, toddlers, pregnant and breastfeeding.
\end{abstract}

Keywords: Service Quality, Five Dimension of Service Quality, Passport.

\begin{abstract}
ABSTRAK
Tujuan penelitian ini adalah mengetahui Kualitas Pelayanan Pembuatan Paspor di Kantor Imigrasi Kelas I Kota Bogor.

Teori yang digunakan dalam penelitian ini yaitu dengan menggunakan teori yang di kemukakan oleh Parasuraman, Berry dan Zeithaml (Ratminto \& Septi Winarsih, 2005: 175) yang terdiri atas 5 dimensi kualitas pelayanan yaitu Tangible, Reliability, Responsiveness, Assurance dan Empathy. Metode yang digunakan adalah deskriptif analisis dengan menggunakan pendekatan Kuantitatif. Sedangkan teknik analisis data yang digunakan
\end{abstract}


yaitu dengan menggunakan perhitungan Weight Mean Score (WMS). Teknik pengumpulan data yang digunakan adalah studi kepustakaan dan studi lapangan. Populasi penelitian ini berjumlah 220 responden yang terdiri dari Pemohon dan Petugas Paspor. Sedangkan teknik sampling yang digunakan adalah Teknik Samplin Jenuh Untuk Petugas dan Teknik sempling Insidental untuk pemohon. Penentuan sampel menggunakan rumus Yamane sehingga sampel yang diperoleh adalah 87 responden.

Hasil penelitian Kualitas pelayanan Pembuatan paspor di Kantor Imigrasi Bogor dinilai sudah Baik, karena dari hasil pengolahan angket yang dilakukan kepada 67 sample pemohon paspor diperoleh skor 3,67 dimana termasuk dalam kategori Baik. sekalipun demikian masih banyaknya keluhan yang dirasakan oleh para pemohon. Hal ini terjadi dikarenakan kurang luasnya ruang tunggu untuk pemohon,kecepatan penyelesaian pembuatan paspor,jaminan tepat waktu dalam penyelesaian paspor, dan perlakuan diskriminatif yang sebenarnya diperuntukkan bagi para Lansia, Balita, Ibu Hamil dan Menyusui.

Kata Kunci: Kualitas Pelayanan, Lima Dimensi Kualitas Pelayanan, Paspor.

Suciani Cahya Bintari, 2017. Kualitas Pelayanan Pembuatan Paspor Di Kantor Imigrasi Kelas I Kota Bogor. Jurnal Governansi. 


\section{PENDAHULUAN}

Pelayanan publik di Indonesia memiliki peranan penting pada kehidupan ekonomi, sosial dan politik, pelayanan juga merupakan unsur penting dalam meningkatkan kualitas hidup sosial di dalam masyarakat. Mengingat pelayanan publik memiliki implikasi yang luas dalam keidupan ekonomi, sosial dan politik, akan tetapi kualitas pelayanan publik sampai saat ini secara umum masih belum baik. Buruknya kualitas menimbulkan krisis kepercayaan di masyarakat terhadap birokrasi publik, krisis kepercayaan ditunjukkan dengan munculnya berbagai bentuk protes dan demonstrasi kepada birokrasi baik ditingkat pusat maupun daerah. Saat ini masyarakat masih merasakan prosedur dan mekanisme pelayanan yang berbelit - belit, tidak transparan, kurang informatif, kurang akomodatif dan kurang konsisten sehingga tidak menjamin kepastian hukum, waktu dan biaya. Sehingga hal tersebut mengakibatkan munculnya fenomena lain seperti kebut-kebutan yang difaktori oleh pengaruh lingkungan seperti terjadinya balapan hingga melanggar marka jalan dan rambu dijalan yang kian dapat menggangu pengguna jalan lain yang dapat mengakibatkan kecelakaan bahkan kematian.

Pemerintah harus menyediakan pelayanan yang berkualitas, dan itu sangat tergantung pada berbagai aspek, yaitu bagaimana pola penyelenggaraannya (tata laksana) dan dukungan sumber daya manusia dan kelembagaan, dilihat dari sisi pola penyelenggaraannya, pelayanan publik masih memiliki berbagai kelemahan antara lain : kurang responsif, kurang informatif, kurang accessible, kurang koordinasi, birokrasi, kurang mau mendengar keluhan/ saran/aspirasi masyarakat. Untuk mengatasi masalah pelayanan publik yang buruk ini, maka seharusnya pemerintah melakukan reformasi birokrasi dalam rangka meningkatkan kualitas pelayanan pemerintah pada masyarakat.
Dalam Peraturan Menteri Hukum dan Hak Asasi Manusia Republik Indonesia Nomor 8 Tahun 2014 Pasal 2 tentang Paspor Biasa dan Surat Perjalanan Laksana Paspor disebutkan bahwa permohonan paspor biasa dapat diajukan oleh warga negara Indonesia di wilayah Indonesia dan di Luar wilayah Indonesia dan Paspor biasa terdiri atas Paspor biasa Elektronik dan Paspor biasa Non Elektronik. Paspor biasa Elektronik diterbitkan dengan menggunakan Sistem Informasi Manajemen Keimigrasian disertasi dengan melampirkan kelengkapan dokumen persyaratan. Sedangkan menurut Pasal 3 Dalam Peraturan Menteri Hukum dan Hak Asasi Manusia Republik Indonesia Nomor 8 Tahun 2014 tentang Paspor Biasa dan Surat Perjalanan Laksana Papor disebutkan bahwa Permohnan Paspor biasa dapat diajukan secara manual dan elektronik dengan melampirkan dokumen kelengkapan persyaratan.

Permasalahan yang sering dikeluhkan oleh para pemohon Paspor dilihat dari lima dimensi utama yang dikemukakan oleh Parasuraman, Zeithmal dan Berry diantaranya, yaitu :

1. Kurang luasnya Ruang yang disediakan untuk pelayanan

2. Kejelasan informasi persyaratan pembuatan paspor

3. ketiadaan lahan parkir di Kantor Imigrasi

4. Kurang ramahnya petugas pembuat paspor.

Menyikapi fenomena - fenomena tersebut sudah seharusnyalah Direktorat Jenderal Imigrasi mengambil langkah kongkrit agar pelayanan pengurusan paspor dapat terimplementasi dengan baik dan berhasil memenuhi kepuasan publik, maka dapat dikatakan bahwa pemerintah dalam memberikan pelayanan telah meningkatkan dan memperbaiki kualitas pelayanan selaku aparatur pemerintah. Selain itu bila terbukti pula aparatur pemerintah di Kantor Imigrasi Kelas I Kota Bogor telah menerapkan kualitas pelayanan yang baik dalam pelayanan khususnya 
pelayanan pembuatan paspor. Maka hal ini telah menjadi tolak ukur sekaligus sebagai spirit guna menjawab tantangan perubahan ke arah perbaikan pelayanan dalam rangka memenuhi kebutuhan rakyat demi terwujudnya kesejahteraan rakyat.

Tabel 1

Data Petugas Pengurus Paspor 2017

\begin{tabular}{lc}
\hline \multicolumn{1}{c}{ Jenis } & Jumlah \\
\hline Kelamin & 17 \\
Paki - Laki & 3 \\
Jumlah & 20 \\
\hline
\end{tabular}

Dari tabel 1 dapat diketahui bahwa petugas pengurus paspor berjumlah 20 orang.

\section{MATERI DAN METODE}

Menurut Sugiyono (2007:1) metode penelitian pada dasarnya merupakan cara ilmiah untuk mendapatkan data dengan tujuan dan kegunaan tertentu. Metode penelitian merupakan ilmu yang mempelajari tentang metode-metode penelitian, ilmu tentang alat-alat dalam penelitian, dilingkungan filsafat, logika dikenal sebagai ilmu tentang alat-alat untuk mencari kebenaran. Bila ditata dalam sistematika, metodologi penelitian merupakan bagian dari logika (Neong Muhadjir, 1998:140)

Menurut Sugiyono

menjelaskan penelitian deskriptif analisis adalah penelitian yang dilakukan untuk mengetahui nilai variabel mandiri, baik satu variabel atau lebih ( independen ) tanpa membuat perbandingan, atau menghubungkan antara variabel satu dengan variabel yang lain

Teori yang digunakan dalam penelitian ini yaitu dengan menggunakan teori yang di kemukakan oleh Parasuraman, Berry dan Zeithaml ( Ratminto \& Septi Winarsih, 2005: 175 ) yang terdiri atas 5 dimensi kualitas pelayanan yaitu :
1. Tangible (Berwujud)
2. Reliability (Kehandalan)
3. Responsiveness (Daya Tanggap)
4. Assurance (Jaminan)
5. Empathy (Empati)

Metode yang digunakan pada penelitian ini adalah metode Deskriptif. Analisis. Menurut sugiyono (2012:11) adalah penelitian yang dilakukan untuk mengetahui nilai variabel mandiri, baik satu variabel atau lebih ( independen ) tanpa membuat perbandingan, atau menghubungkan antara variabel satu dengan variabel yang lain. Penelitian ini menggunakan pendekatan kuantitatif.

\section{Populasi dan Sampel}

Menurut sugiyono populasi adalah wilayah generalisasi yang terdiri atas : objek/subjek yang mempunyai kualitas dan karakteristik tertentu yang ditetapkan oleh peneliti untuk dipelajari dan kemudian ditarik kesimpulannya.

Populasi dalam penelitian ini adalah 220 Orang dimana 200 Orang sebagai Pemohon Paspor dan 20 Orang sebagai Petugas Pembuat Paspor.

Dari populasi tersebut dapat ditarik sampel. Sampel adalah bagian dari jumlah karakteristik yang dimiliki oleh populasi tersebut dan sampel yang digunakan dalam penelitian ini yaitu sampel jenuh dan sampel insidental.

Selanjutnya untuk mendapatkan besaran jumlah sampel dalam penelitian ini menggunakan rumus untuk menghitung besarnya sampel yang diperlukan dalam penelitian ini adalah menggunakan rumus Yamane yang dikutip oleh Rahmat (1999:133) sebagai berikut :

$$
\mathbf{n}=\frac{\mathbf{N}}{\mathbf{N d}^{2}+\mathbf{1}}
$$

Keterangan :

n : Ukuran sampel

$\mathrm{N}$ : Populasi

d : Tingkat kesalahan ditetapkan secara sengaja sebesar $10 \%$

sumber Yamane dalam Rahmat (1999:113) 
Tabel 2

Populasi di Kantor Imigrasi Bogor

\begin{tabular}{|c|c|}
\hline Klasifikasi & jumlah \\
\hline Petugas pembuat & 20 \\
\hline Paspor di Kantor & \\
\hline Imigrasi Kelas I Kota & \\
\hline Bogor & \\
\hline Pemohon & 200 \\
\hline Paspor di Kantor & \\
\hline Imigrasi Kelas I Kota & \\
\hline Bogor & \\
\hline Total Populasi & 220 \\
\hline
\end{tabular}

Sumber : Hasil Penelitian 2017

Sampel Pemohon di Kantor Imigrasi Bogor 67 Orang, Sampel petugas di Kantor Imigrasi Bogor yaitu sebanyak 20 Orang.

Dari hasil penelitian tersebut, maka jumlah sampel representative yang digunakan dalam penelitian ini adalah sebanyak 87 (delapan puluh tujuh) orang baik pemohon maupu petugas.

\section{Teknik Pengumpulan Data}

Untuk memperoleh data yang diperlukan, maka penulis menggunakan beberapa teknik pengumpulan data sebagai berikut:

1. Teknik pengumpulan data primer
a. Kuesioner (angket)
b. Observasi
c. Wawancara

2. Teknik pengumpulan data sekunder

a. Studi kepustakaan,

b. Dokumentasi

\section{Teknis Analisis Data}

rumus WMS.

Dalam penelitian ini menggunakan

$$
\mathrm{M}=\frac{\sum(\mathrm{fx})}{\mathrm{n}}
$$

\section{HASIL DAN PEMBAHASAN}

Berdasarkan hasil penelitian, Kualitas pelayanan Pembuatan paspor di Kantor Imigrasi Bogor dinilai sudah Baik, karena dari hasil pengolahan angket yang

dilakukan kepada 67 sample pemohon paspor diperoleh skor 3,67 dimana termasuk dalam kategori Baik. Kualitas Pelayanan menggunakan 5 dimensi yaitu tanginble,Reliability,Responsiveness,Assura nce, Empathy. Berikut rekapitulasi Kualitas Pelayanan Pembuatan Paspor :

\section{Tabel 3}

Rekapitulasi Kualitas Pelayanan Pembuatan Paspor

\section{Dimensi}

Dim


- Petugas melakukan pelayanan tepat waktu

- Tanggap

Assuranc e dalam memberika 3,78 Baik $\mathrm{n}$ pelayanan.

- Keluhan Pemohon direspon oleh petugas.

- Petugas memberika $\mathrm{n}$ jaminan tepat waktu dalam pelayanan;

- Jaminan biaya dalam 4,04 Baik pelayanan;

- Jaminan legalitas dalam 3,78 Baik pelayanan.

- Mendahulu kan

Empathy kepentinga $n$ pemohon

- Petugas melayani dengan tidak diskriminat 2,84 Sedang if (membeda - bedakan);

- Petugas melayani dan 3,76 Baik menghargai pemohon;

- Petugas melayani dengan

Baik sikap

ramah.

Jumlah

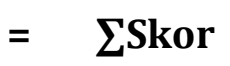

Jumlah indikator

Dari Tabel menunjukkan bahwa Kualitas Pelayanan Pembuatan Paspor di Kantor Imigrasi Kelas 1 Kota Bogor menurut survey yang dilakukan kepada 67 Responden Pemohon Paspor termasuk dalam kategori Baik dengan nilai 3,67. Dari 22 Indikator diatas, yang mempunyai nilai tertinggi yaitu Indikator Penampilan petugas dalam melayani pemohon dimana mendapatkan nilai 4,06 dengan kategori Baik, hal ini dikarenakan selama lima hari kerja, petugas selalu mengenakan pakaian yang sopan dan diwajibkan memakai seragam dan memakai name tag sehingga dapat dikenali oleh para pemohon. Tetapi untuk indikator yang mempunyai nilai terendah yaitu petugas melayani dengan tidak diskriminatif (membeda-bedakan) mendapatkan nilai 2,84 yang termasuk dalam kategori Sedang. Disini para pemohon menilai masih ada perlakuan diskriminatif dari para petugas, bukan maksud petugas untuk mebeda-bedakan, tetapi petugas lebih mendahulukan pelayanan perioritas kepada lansia, ibu hamil menyusui, dan juga kepada balita dimana mereka didahulukan kepentingannya oleh para petugas. dan empat indikator berada pada kriteria sedang dimana empat indikator tersebut yaitu kenyamanan Tempat yang memiliki nilai 3,37 dengan kategori sedang, hal ini dikarenakan tempat yang dijadikan ruang tunggu kurang luas sehingga terpaksa banyak yang berdiri saat mengantri dan untuk pengecekan kelengkapan persyaratan dilakukan diluar gedung. melakukan pelayanan dengan cepat memiliki nilai 3,33 , petugas memberikan jaminan tepat waktu untuk penerbitan paspor mempunyai nilai 3,3 dan pelayanan yang tidak diskriminatif juga mempunyai nilai 2,84 tetapi, Dengan demikian bisa 
disimpulkan bahwa berdasarkan pendapat responden Kualitas Pelayanan di Kantor Imigrasi Bogor telah dilaksanakan dengan baik meskipun ada beberpa indikator yang harus ditingkatkan lagi demi mewujudkan kualitas pelayanan yang lebih baik lagi.

\section{Tabel 4}

Rekapitulasi Kualitas Pelayanan Pembuatan Paspor

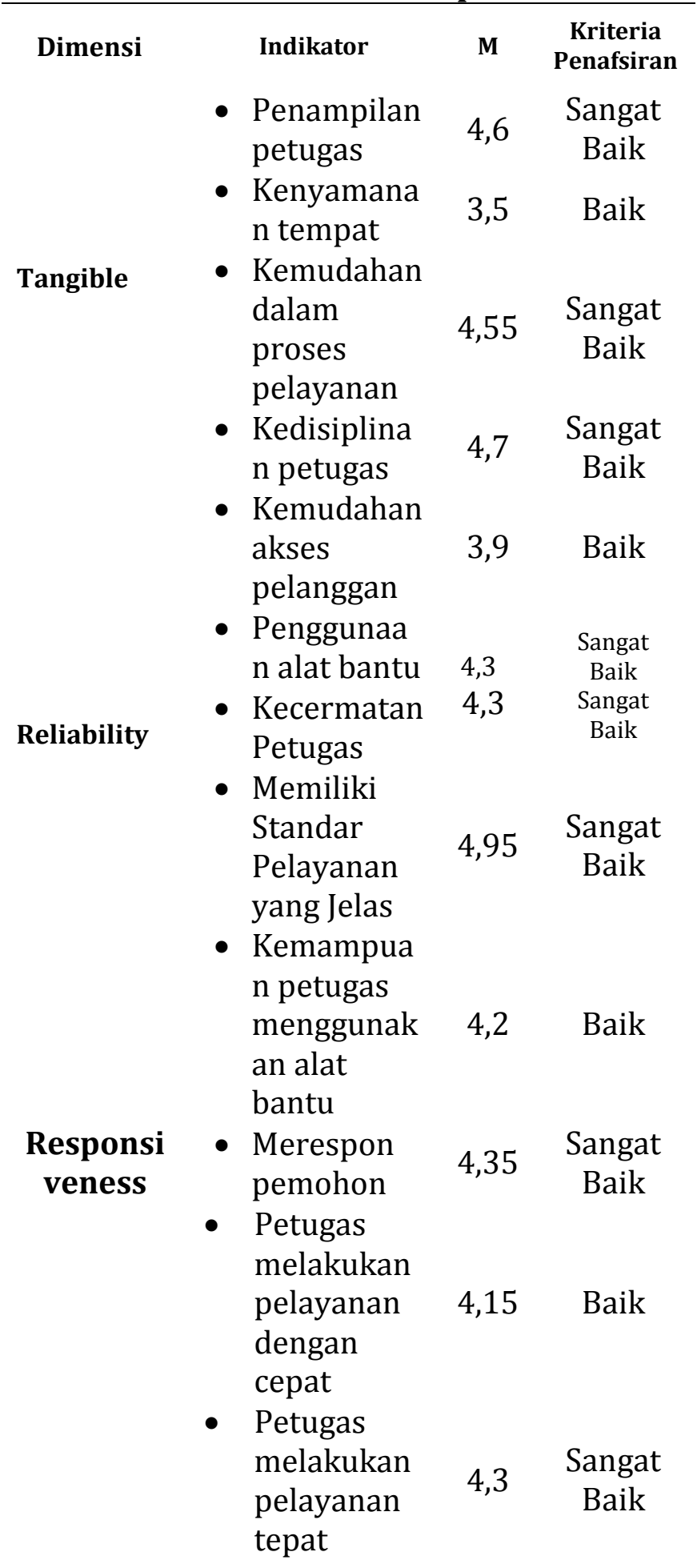

- Petugas melakukan pelayanan $\quad 4,1 \quad$ Baik tepat waktu

- Tanggap

Assuran ce dalam pelayanan.

4,3 Sangat

- Keluhan Pemohon direspon oleh 4,3 Sangat petugas.

- Petugas memberika $\mathrm{n}$ jaminan tepat 3,65 Baik waktu dalam pelayanan;

- Jaminan biaya dalam 4,6 Sangat pelayanan;

- Jaminan legalitas dalam Sangat
Baik pelayanan.

- Mendahulu Empath kan kepentinga 4,7 Baik n pemohon

- Petugas melayani dengan tidak diskriminat $4,7 \quad$ Sangat if (membeda - bedakan);

- Petugas melayani dan menghargai pemohon;

- Petugas melayani dengan sikap ramah. 


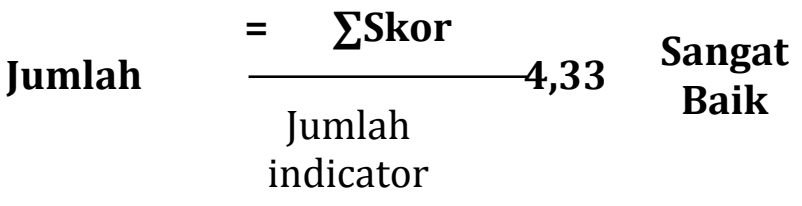

Dari Tabel menunjukkan bahwa Kualitas Pelayanan Pembuatan Paspor di Kantor Imigrasi Kelas 1 Kota Bogor menurut survey yang dilakukan kepada 20 Responden Petugas Paspor termasuk dalam kategori Sangat Baik dengan nilai 4,33. Dari 22 Indikator diatas, yang mempunyai nilai tertinggi yaitu Indikator Memiliki Standar Pelayanan yang Jelas dimana mendapatkan nilai 4,95 dengan kategori Sangat Baik, Hal ini dikarenakan Para Petugas selalu mengacu kepada SOP (Standart Operating Prosedur) dalam meberikan pelayanan, Tetapi untuk indikator yang mempunyai nilai terendah yaitu Kenyamanan tempat melakukan Pelayanan mendapatkan nilai 3,5 yang termasuk dalam kategori Sedang. Para petugas merasa bahwa tempat yang digunakan untuk melakukan pelayanan dirasa sudah harus diperluas mengingat semakin banyaknya jumlah pemohon paspor yang datang setiap harinya. Namun dengan hasil penilaian demikian menujukkan bahwa Pelayanan di Kantor Imigrasi Bogor telah dilaksanakan dengan baik.

\section{Pembahasan}

Kualitas Pelayanan Pembuatan Paspor di Kantor Imigrasi Bogor menurut survey yang dilakukan kepada 67 Pemohon Paspor memiliki nilai 3,67 dan termasuk dalam kategori Baik. Dari 22 Indikator diatas, yang mempunyai nilai tertinggi yaitu Indikator Penampilan petugas dalam melayani pemohon dimana mendapatkan nilai 4,06 dengan kategori Baik, hal ini dikarenakan selama lima hari kerja, petugas selalu mengenakan pakaian yang sopan dan diwajibkan memakai seragam dan memakai name tag sehingga dapat dikenali oleh para pemohon. Tetapi untuk indikator yang mempunyai nilai terendah yaitu petugas melayani dengan tidak diskriminatif (membeda-bedakan) mendapatkan nilai 2,84 yang termasuk dalam kategori Sedang. Disini para pemohon menilai masih ada perlakuan diskriminatif dari para petugas, bukan maksud petugas untuk mebedabedakan, tetapi petugas lebih mendahulukan pelayanan perioritas kepada lansia, ibu hamil menyusui, dan juga kepada balita dimana mereka didahulukan kepentingannya oleh para petugas.

Dan Kualitas Pelayanan Pembuatan Paspor di Kantor Imigrasi Bogor menurut survey yang dilakukan kepada 20 Petugas Paspor termasuk dalam kategori Sangat Baik dengan nilai 4,33. Dari 22 Indikator yang mempunyai nilai tertinggi yaitu Indikator Memiliki Standar Pelayanan yang Jelas dimana mendapatkan nilai 4,95 dengan kategori Sangat Baik, Hal ini dikarenakan Para Petugas selalu mengacu kepada SOP (Standart Operating Prosedur) dalam meberikan pelayanan, Tetapi untuk indikator yang mempunyai nilai terendah yaitu Kenyamanan tempat melakukan Pelayanan mendapatkan nilai 3,5 yang termasuk dalam kategori Sedang. Para petugas merasa bahwa tempat yang digunakan untuk melakukan pelayanan dirasa sudah harus diperluas mengingat semakin banyaknya jumlah pemohon paspor yang datang setiap harinya.

Standar Prosedur yang ditetapkan oleh Kantor Imigrasi selalu berusaha dipatuhi oleh setiap petugas sehingga pemohon merasa dilayani dengan baik oleh para petugas, selain itu Para petugas pun sudah mengerti dengan Tugas dan Fungsi mereka sehingga tidak ada lagi tumpang tindih pekerjaan antara petugas yang satu dan petugas yang lain. Petugas pun berusaha untuk melakukan pekerjaan dengan tepat waktu, berpenampilan dengan baik untuk melayani pemohon, memberikan kenyamanan dari segi tempat, menguasai alat bantu seperti kemahiran mengendalikan komputer dan scanning, cermat dalam memeriksa setiap detail berkas permohonan pemohon, kemampuan petugas untuk menerima pemohon yang mengajukan permohonan lewat jalur 
online, merespon setiap pemohon dengan sebaik mungkin, pemohon mendapatkan kepastian baya dalam permohonan paspor, kemudahan dalam proses pelayanan, kedisiplinan para petugas dan kepentingan pemohon menjadi prioritas para petugas dalam memberikan pelayanan.

Akan tetapi ada beberapa permasalahan yang dikeluhkan oleh para pemohon seperti kurang luasnya ruang tunggu, Kurang ramahnya para petugas, hanya ada 2 orang petugas yang melakukan pengecekan berkas sehingga para pemohon harus mengantri untuk pengecekan berkas permohonna, sistem online yang masih bermasalah sehingga banyak pemohon yang akhirnya mengurus permohonan walk-in (datang langsung), waktu penerbitan paspor tidak sesuai dengan Surat Edaran Direktorat Jenderal Imigrasi yaitu 3 Hari Kerja setelah pembayaran, hal tersebut menjadi PR para petugas yang harus segera dicarikan solusinya sehingga para pemohon merasa lebih puas dengan pelayanan yang diberikan oleh Kantor Imigrasi Bogor.

Hambatan yang dihadapi para petugas dalam pelayanan paspor yaitu masalah sistem yang sering terganggu, sehingga pendataan pemohon yang harus dilaporkan ke Direktorat Jenderal Imigrasi Nasional bahwa yang bersangkutan telah membuat paspor sering terhambat, dan juga akses masuk ke web Ditjen Imigrasi untuk pembuatan paspor secara online yang sulit karena terlalu banyaknya masyarakat yang mencoba mengakses web tersebut untuk membuat paspor secara online. hal ini pun telah dilaporkan kepada Ditjen Imigrasi Nasional dan masih terus dalam rangka perbaikan agar permohonan paspor secara online dan pendataan pemohon dapat dilakukan sebagaimana mestinya. dan juga Hambatan lainnya yang sering ditemui oleh para petugas yaitu tidak jarang masyarakat keliru pada saat pengisian formulir, misalnya seperti si pemohon ingin mengajukan permohonan perpanjangan paspor, tetapi si pemohon mengisi formulir untuk pembutan paspor baru. setelah diproses ternyata data si pemohon telah ada sebagai pemegang paspor, dan disinilah Hal yang menjadi hambatan untuk para petugas menerbitkan paspor, dalam kasus seperti ini, yang dilakukan oleh petugas akan memanggil kembali si pemohon dan mengkroscek kebenrannya, apakah si pemohon sudah memiliki paspor sebelumnya atau tidak, jika ternyata sudah memiliki paspor maka formulir permohonan dikembalikan lagi dan si pemohon diminta untuk mengisi formulir dengan maksud perpanjangan paspor.

Upaya - Upaya yang dilakukan kantor Imigrasi Bogor dalam rangka meningkatkan Kualitas Pelayanan Pembutan Paspor di Kantor Imigrasi Bogor diantaranya yaitu :

1. Ketepatan dalam penerbitan Paspor, para petugas selalu berusaha untuk memasukkan identitas calon pemegang paspor dengan tepat sesuai yang tertera di formulir permohonan, sebelum diberikan kepada pemohon, paspor melewati uji kualitas apakah paspor ini sudah layak atau belum untuk digunakan.

2. Ketepatan waktu dalam penyelesaian paspor, selama 3 hari pengerjaan setelah pembayaran. namun.

3. kejelasan dalam prosedur pembuatan paspor, dimana kekeliruan dalam pengisian formulir dapat diminimalisir kesalahannya,contohnya seperti, pemohon dapat mengisi formulir dengan Permohonan Paspor Baru jika memang belum mempunyai paspor sebelumnya, atau permohonan perpanjangan paspor bagi pemohon yang mempunyai paspor sebelumnya dan akan habis masa berlaku ataupun paspor sebelumnya hilang. Para pemohon harus melampirkan KTP Elektronik, Kartu Keluarga, dan Akte yang didalamnya memuat nama orangtua atau jika tidak memiliki akte bisa menggunakan ijazah ataupun buku nikah, disertakan dengan fotocopy nya, mengisi formulir permohonan, dan bersedia mengikuti proses sidik jari, 
wawancara, dan rekam wajah setlah itu melakukan pembayaran di Bank yang telah direkomendasikan.

4. Adanya pelayanan prioritas terhadap Lansia, anak kecil, Ibu hami dan Menyusui, dan disediakan ruang untuk menyusui di Kantor Imigrasi Bogor.

5. Dibuatnya rak nomor antrian map, untuk menertibkan antrian pemohon paspor;

6. Adanya pelayanan di jam istirahat, secara bergantian dengan dibuka satu booth;

7. Sistem antrian pengambilan paspor dengan aplikasi penyimpanan paspor yang berbasis web;

8. Adanya fasilitas snack dan coffee break di ruang tunggu pemohon paspor.

9. Jika ada Keluhan, Kritik dan Saran Kepada Kantor Imigrasi Kelas I Kota Bogor, Kantor Imigrasi Bogor menyediakan layanan pengaduan masyarakat dengan cara:

a. Sms Call Center ke Nomor : 081$111-998-66$

b. Atau dengan telfon ke Nomor : 0251 $-8382-275$

c. Bisa juga melalu media sosial, yaitu : 1. Fanpage Facebook : Imigrasi Bogor. 2. Twitter : @KanimBogor, 3. Website resmi kantor Imigrasi Bogor : bogor.imigrasi.go.id

d. Atau langsung kepada Direktorat Jenderal Imigrasi (Ditjen) Imigrasi Pusat dengan menggunakan Program LAPOR (Layanan Aspirasi dan Pengaduan Online Rakyat) dimana jika masyarakat memberi pengaduan lewat Program LAPOR kantor Imigrasi wilayah terkait belum bisa menindak lanjuti laporan yang diadukan masyarakat tersebut, dimana dalam artian laporan dari masyarakat ditindaklanjuti dulu oleh Kemenkumham, setelah itu ditindak lanjuti oleh Ditjen Imigrasi baru jika tidak selesai juga maka akan diserahkan kepada kantor imigrasi wilayah terkait. (top-down)

\section{KESIMPULAN DAN IMPLIKASI}

Berdasarkan hasil penelitian yang telah dilakukan, maka dapat ditarik kesimpulan sebagai berikut :

1. Setelah dilakukan pengolahan angket terhadap setiap indikator dari variabel Kualitas Pelayanan di Kantor Imigrasi Kelas I Kota Bogor diperoleh skor bahwa rata-rata hasil penilaian pemohon paspor untuk seluruh indikator adalah sebesar 3,67 dan menurut kriteria penafsiran berada pada klasifikasi penilaian baik. Indikator yang mempunyai nilai tertinggi yaitu Indikator Penampilan petugas dalam melayani pemohon dengan nilai 4,06. Hal ini didukung berdasarkan Penampilan petugas dalam melayani yang selalu mengenakan seragam dan name tag dan berpenampilan sopan dalam melayani. Sedangkan skor rata rata hasil penilaian petugas adalah 4,33 yang artinya berada pada klasifikasi penilaian Sangat Baik. dengan demikian kualitas pelayanan penilaian kualitas pelayanan pembuatan paspor di kantor imigrasi kelas I Kota Bogor sudah baik, akan tetapi berdasarkan wwancara dan hasil observasi terdapat beberapa indikator yang harus ditingkatkan lagi yaitu Perlakuan petugas yang tidak diskriminatif (membeda-bedakan), ruang tunggu yang harus di perbesar, keramahan pegawai yang harus lebih bersahabat lagi dengan pemohon, kemampuan menjelaskan prosedur pembuatan paspor kepada pemohon, ketepatan waktu dalam penerbitan paspor. 
2. Kualitas Pelayanan Pembuatan Paspor di Kantor Imigrasi Kelas 1 Kota Bogor menurut survey yang dilakukan kepada 20 Responden Petugas Paspor termasuk dalam kategori Sangat Baik dengan nilai 4,33. Indikator yang mempunyai nilai tertinggi yaitu Indikator Memiliki Standar Pelayanan yang Jelas dimana mendapatkan nilai 4,95 dengan kategori Sangat Baik, Hal ini dikarenakan Para Petugas selalu mengacu kepada

3. Hambatan yang dialami oleh para petugas dalam memberikan Pelayanan Pembuatan Paspor yaitu masalah sistem yang sering terganggu. sehingga pendataan pemohon yang harus dilaporkan ke Direktorat Jenderal Imigrasi Nasional bahwa yang bersangkutan telah membuat paspor sering terhambat, dan juga tidak jarang petugas menemukan kesalahan dalam pengisian formulir, jika misalnya seperti si pemohon ingin mengajukan permohonan perpanjangan paspor, tetapi si pemohon mengisi formulir untuk pembutan paspor baru. setelah diproses ternyata data si pemohon telah ada sebagai pemegang paspor, dan disinilah Hal yang menjadi hambatan untuk para petugas menerbitkan paspor, dalam kasus seperti ini, yang dilakukan oleh petugas akan memanggil kembali si pemohon dan mengkroscek kebenrannya, apakah si pemohon sudah memiliki paspor sebelumnya atau tidak, jika ternyata sudah memiliki paspor maka formulir permohonan dikembalikan lagi dan si pemohon diminta untuk mengisi formulir dengan maksud perpanjangan paspor.

4. Upaya yang dilakukan dalam rangka meningkatkan kualitas pelayanan di kantor imigrasi bogor yaitu, ketepatan dalam penerbitan paspor dimana paspor yang akan diberikan sudah melalui uji kualitas sehingga dipastikan tidak akan terjadi kesalahan pada identitas pemegang paspor, ketepatan waktu dalam penerbitan paspor yaitu selam tiga hari kerja,adanya pelayanan oprioritas kepada pemohon paspor lansia, ibu hamil dan menyusi, dan balit, tersedianya Pelayanan pengaduan Pemohon yang siap melayani dan memberikan solusi jika terjadi hambatan dalam Pembuatan Paspor.

\section{Implikasi Teoritis}

Teori yang digunakan dalam penelitian ini yaitu dengan menggunakan teori yang di kemukakan oleh Parasuraman, Berry dan Zeithaml ( Ratminto \& Septi Winarsih, 2005: 175 ) yang terdiri atas 5 dimensi kualitas pelayanan yaitu Tangible, Reliability, Responsiveness, Assurance dan Empathy.

Penelitian ini menggunakan tujuantujuan tersebut sebagai kriteria untuk menentukan keberhasilan pelayanan. Teori ini dianggap lebih praktis untuk menetukan penilaian kualitas pelayanan ini akan menjadi lebih praktis.

\section{Implikasi Praktis}

1. kualitas pelayanan dalam ilmu administrasi baru memang menjadi tolak ukur keberhasilan dalam sebuah organisasi pemerintah maupun swasta dalam memberikan pelayanan kepada masyarakat.

Dalam memberikan pelayanan yang berkualitas memerlukan biaya dan kesiapan pegawai dalam melakukan pelayanan agar berjalan maksimal. Efektivitas pelaksanaan pelayanan sangat bergantung pada kecukupan dana yang tersedia dan kesiapan para pegawai dalam melaksanakan pelayanan. 


\section{DAFTAR PUSTAKA}

\section{Sumber Undang-Undang :}

Undang - Undang Nomor 8 Tahun 2014 Tentang Surat Perjalanan Republik Indonesia (Paspor)

\section{Sumber Buku :}

Pelayanan Publik. Yogyakarta : Gadjah Mada University Press.

Hardiyansyah, (2011) Kualitas Pelayanan Publik (Konsep, Dimensi, Indikator dan Implementasinya). Yogyakarta : Penerbit Gava Media.

Sugiyono, (2011) Metode Penelitian Administrasi. Bandung: Penerbit Afabeta

Tjiptono, Fandy. 2008. Service Management: Mewujudkan Layanan Prima. Yogyakarta: Andi

Pedoman Skripsi. Fisip Unida. 2014

\section{Sumber Skripsi :}

Tayyib, Muhammad. (2015) Kualitas Pelayanan Paspor di Kantor Imigrasi Kelas I Makassar, Makassar: FISIP Universitas Hasannudin.

\section{Sumber Jurnal :}

Wicaksono, Kristian W. (2015). Kualitas Pelayanan Pembuatan Paspor di Kantor Imigrasi Kelas I Bandung, Banten: FISIP Universitas Sultan Ageng Tirtayasa. 